Review

\title{
Hydroxychloroquine/Chloroquine as Therapeutics for COVID-19: Truth under the Mystery
}

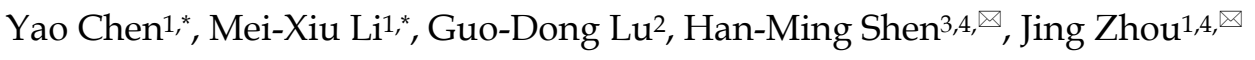 \\ 1. Department of Physiology, School of Preclinical Medicine, Guangxi Medical University, Nanning, Guangxi Province, China, 530021. \\ 2. Department of Toxicology, School of Public Health, Guangxi Medical University, Nanning, Guangxi Province, China, 530021. \\ 3. Faculty of Health Sciences, University of Macau, Taipa, Macau, China \\ 4. Department of Physiology, Yong Loo Lin School of Medicine, National University of Singapore, Singapore \\ * These authors contributed equally to this work.
}

$\square$ Corresponding authors: Jing Zhou, Department of Physiology, School of Preclinical Medicine, Guangxi Medical University, P.R. China. E-mail address: gardenia_zhou@hotmail.com, ORCID: 0000-0002-2475-7783. Han-Ming Shen, Faculty of Health Sciences, University of Macau, Macau, China. Email: hmshen@um.edu.mo, ORCID: 0000-0001-7369-5227

(1) The author(s). This is an open access article distributed under the terms of the Creative Commons Attribution License (https://creativecommons.org/licenses/by/4.0/). See http://ivyspring.com/terms for full terms and conditions.

Received: 2021.02.18; Accepted: 2021.03.02; Published: 2021.04.10

\begin{abstract}
The outbreak of coronavirus disease-19 (COVID-19) caused by severe acute respiratory syndrome coronavirus 2 (SARS-CoV-2) has rapidly evolved into a global pandemic. One major challenge in the battle against this deadly disease is to find effective therapy. Due to the availability and proven clinical record of hydroxychloroquine (HCQ) and chloroquine (CQ) in various human diseases, there have been enormous efforts in repurposing these two drugs as therapeutics for COVID-19. To date, substantial amount of work at cellular, animal models and clinical trials have been performed to verify their therapeutic potential against COVID-19. However, neither lab-based studies nor clinical trials have provided consistent and convincing evidence to support the therapeutic value of HCQ/CQ in the treatment of COVID-19. In this mini review we provide a systematic summary on this important topic and aim to reveal some truth covered by the mystery regarding the therapeutic value of $\mathrm{HCQ} / \mathrm{CQ}$ in COVID-19.
\end{abstract}

Key words: COVID-19, SARS-CoV-2, HCQ, CQ, therapy, clinical trials

\section{Introduction}

The outbreak of COVID-19 caused by SARS-CoV-2 has caused a global public health emergency and serious economic crisis. Since December 2019, it has rapidly spread around the world and affected more than 200 countries and regions. According to WHO statistics, the outbreak of COVID-19 has caused more than 100 million confirmed cases and 2 million deaths. Globally there is an urgent demand for effective and affordable therapies and vaccines for the treatment and prevention, respectively.

The endo-lysosomal network is particularly important for the entry of coronavirus $(\mathrm{CoV})$ into host cells, and this pathway has become an attractive therapeutic target for the development of antiviral agents [1]. HCQ/CQ have a variety of pharmacological activities, and the mechanism of their anti-CoV (including SARS-CoV-2) effect has not been fully elucidated. Current studies have shown that HCQ/CQ can prevent CoVs from recognizing the receptor, inhibiting the acidification of endosomes that interferes with membrane fusion, and suppressing immunomodulatory process [2]. Furthermore, HCQ/CQ promote the production of immunosuppressive factors IL-6 and TNFa and activate p38 MAPK [3]. These mechanisms may work together to exert their therapeutic effect on SARS-CoV-2. A number of in vitro studies have shown that HCQ/CQ are effective on several types of $\mathrm{CoV}$ that causing human diseases, such as severe acute respiratory syndrome coronavirus (SARS-CoV) [4], Middle East respiratory syndrome coronavirus (MERS-CoV) [5], and SARS-CoV-2 [6-8]. However, in animal models, HCQ/CQ treatment could aggravate infection and cause unfavorable side-effects [9]. More importantly, HCQ/CQ have shown mixed results in 
recent clinical trials: some with certain therapeutic benefits on the treatment of COVID-19 [10-14]; while others demonstrated the opposite effects: significant side effects and increased mortality [11, 15].

Some recent reviews have demonstrated the possible molecular mechanism of the anti-SARS-CoV-2 effect of HCQ/CQ [16, 17], evaluated the pharmacokinetics [18] and toxicity [19] of HCQ/CQ in clinical investigations. In this mini-review, we will summarize the current investigations of $\mathrm{HCQ} / \mathrm{CQ}$ on SARS-CoV-2 by focusing on in vitro studies, animal models and clinical trials to evaluate the therapeutic potential of HCQ/CQ in the treatment of COVID-19, aiming to clear the mystery that currently cover the truth of HCQ/CQ as potential therapeutics for treatment of COVID-19.

\section{History of $\mathrm{HCQ} / \mathrm{CQ}$ as therapeutics for malaria}

HCQ/CQ have been extensively studied and widely used for the prevention and treatment of malaria for many decades. Quinine, a natural product extracted from the bark of the cinchona tree [20], was first documented to treat malaria in the $17^{\text {th }}$ century [21]. Due to the insufficient supply of quinine in the early $19^{\text {th }}$ century, CQ was synthesized as a candidate substitution for quine as an anti-malaria drug in 1930s [22]. Despite its effective anti-malaria function, CQ was not scaled up for clinical use because of its extreme toxicity. In 1940s, CQ was subsequently resynthesized by the introduction of a hydroxyl group, which was named as HCQ and this defined compound had been shown to be more active but less toxic than CQ [23]. HCQ was first approved in 1955, with a favorable efficacy and a reduced toxicity, compared to CQ [24]. Since then, both HCQ and CQ had been widely used as the first-line anti-malaria drugs.

In addition to the common usage of HCQ and $\mathrm{CQ}$ as anti-malaria drugs, they have been increasingly studied for their repurposing potentials in the treatment of an array of other diseases, such as rheumatoid arthritis, systemic lupus erythematosus, cancer, and other bacterial or viral infectious diseases [25-27]. Notably, since the outbreak of the current COVID-19 pandemic, the antiviral effects and applications of HCQ and CQ in the treatment of COVID-19 have attracted particular interest.

\section{Effects of $\mathrm{HCQ} / \mathrm{CQ}$ on the endocytic pathway in the host cells}

SARS-CoV-2 is an enveloped virus with a positive-sense single-stranded RNA genome, and the viral envelope is coated by spike $(S)$ protein trimers that bind to angiotensin converting enzyme 2 (ACE2) receptor, which is required for SARS-CoV-2 infection on host cells [28]. To date, the main pathway controlling the entry of virus into the host cells is endocytosis [29]. The endocytic machinery includes several processes, such as macropinocytosis, clathrin-dependent or clathrin-independent endocytosis, caveolae-dependent endocytosis or caveolae-independent endocytosis [30]. As shown in Figure 1, the replication cycle of SARS-CoV-2 consists of the following 5 steps [31]: (i) Attachment: the virus attach to the host receptor ACE2 via the viral spike protein, which will facilitates its internalization; (ii) Endocytosis: viral membrane fuses with the host cell membrane and gets entry via the host endocytic pathway (endosomes and lysosomes); (iii) Release of viral RNA: the internalized virus releases its genome into the cytosol to be replicated (lysosomes); (iv) Synthesis of viral RNA: genomic RNA experiences transcription and translation to produce relevant viral proteins; (v) Package and release: the viral components assemble together to form new virion which exit to extracellular space through exocytosis. Among them, the endocytic pathway is known to be implicated in the internalization, synthesis and the release stages of viral replication [32]. Although the entry mechanisms and the implication of these routes in SARS-CoV-2 infection have not been fully understood, substantial studies have established that the endocytic pathway is the key mechanism controlling the entry of CoVs into the host cells, which usually depends on the low $\mathrm{pH}$ of endocytic organelles, including both endosomes and lysosomes [1]. Thus, antiviral therapies have been developed to limit the spreading of viruses through blocking any one or combination of above steps of virus life cycle [33].

In addition to the endocytic pathway, lysosome also plays a critical role in the maturation stage of autophagy, by fusing with autophagosome and degrading the engulfed contents in the autophagosome [34]. At present, the role of autophagy in viral infection has been widely investigated, while the crosslinks between these two processes are still controversial [1,35]. Earlier studies have demonstrated that autophagy is implicated in the formation of double-membrane vesicles (DMVs) as well as in the replication of mouse hepatitis virus (MHV) and SARS-CoV [36]. In the process of virus infection, autophagy plays either a pro-viral or anti-viral role, depending on the type of virus, experimental approaches, and the cellular environment [36, 37]. Since the outbreak of COVID-19 more than a year ago, there are some studies focusing 
on the interplays between the autophagy machinery and SARS-CoV-2: the autophagic machinery can exert either positive or negative effect on the replication cycle of SARS-CoV-2 and the viral proteins from SARS-CoV-2 have reciprocal effects on the autophagic process [35, 38]. Such an intricate relationship between autophagy and SARS-CoV-2 lays the foundation for the potential therapeutic activity of HCQ/CQ in treatment of COVID-19.

\section{Antiviral effects of $\mathrm{HCQ} / \mathrm{CQ}$ on SARS-CoV-2 in vitro}

Since the COVID-19 outbreak, the potential anti-viral effects of HCQ/CQ have been tested in various in vitro systems, as summarized in Table $\mathbf{1}$. For instance, there were experimental data demonstrating that CQ was effective in the control of SARS-CoV-2 infection in vitro, compared with other anti-viral agents, including ribavirin, penciclovir, nitazoxanide, nafamostat and favipiravir [39]. Time-of-addition assay demonstrated that CQ could interfere with both entry and post-entry phases of the SARS-CoV-2 infection in Vero E6 cells, and authors implied that CQ is able to synergistically modulate immune activity to improve its antiviral activity [39]. Furthermore, another study also demonstrated that CQ could block SARS-CoV-2 replication in a concentration-dependent manner while had little toxicity on the host cells [40]. In a follow-up study of an in vitro work described above [39], authors found that HCQ was effective in inhibiting SARS-CoV-2 infection in vitro [41]; HCQ also could block the entry and post-entry stages of SARS-CoV-2 confirmed by time-of-addition assay, which was also similarly found upon CQ treatment; moreover, both CQ and HCQ inhibit the release of the viral genome which depends on the transport of SARS-CoV-2 along the endocytic pathway [41].

HCQ has also demonstrated to be more effective but less toxic than CQ, suggesting that HCQ could be a better pharmacological candidate for treatment of COVID-19 (Table 1). After SARS-CoV-2 infection, the EC50 for CQ is higher than the EC50 for HCQ in Vero E6 cells [6]. Moreover, treatment with HCQ, but not $C Q$, caused the improvement on the size and number of endolysosomes, [41]. All these evidences indicate that the in vitro anti-SARS-CoV-2 efficacy of HCQ could be better than that of CQ.

\section{Effects of HCQ/CQ on SARS-CoV-2 in animal models}

Various animal models have been utilized to evaluate the therapeutic effect of HCQ/CQ on SARS-CoV-2 infection. Researchers created non-human primate (cynomolgus macaque) models of SARS-CoV-2 infection to investigate the therapeutic potential of HCQ [43]. In their study, the authors found that there is no obvious anti-SARS-CoV-2 effect of HCQ in the initiation of treatment, neither before infection, early after infection (before the peak of the

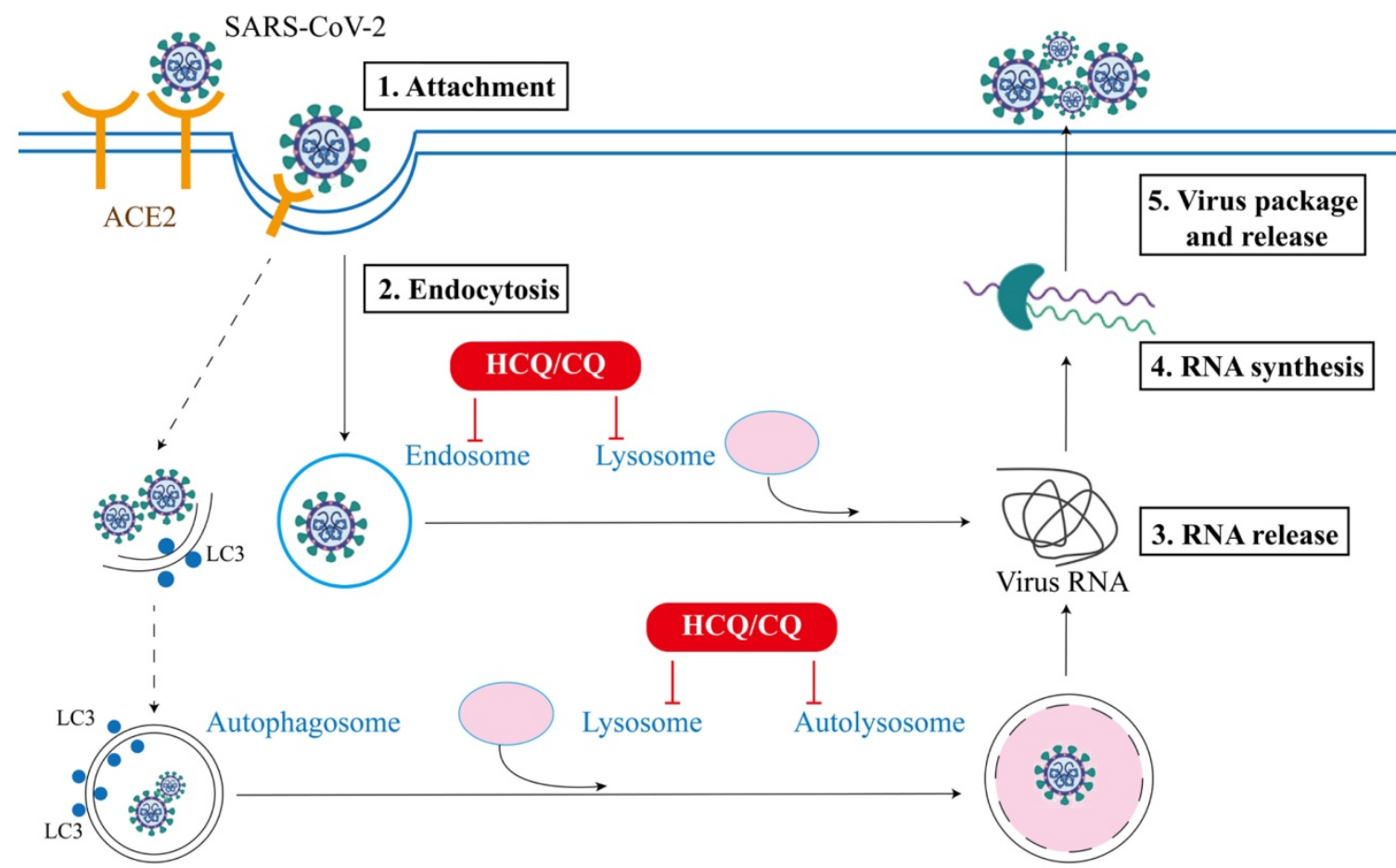

Figure 1. Schematic of SARS-CoV-2 attachment, entry, RNA release and synthesis, and virus assembly and release in the extracellular space. The endocytic pathway plays a critical role in the entry and replication of SARS-CoV-2 and serves as target for the potential therapeutic effects of HCQ/CQ in COVID-19. 
viral load) nor late after infection (after the peak of the viral load). This conclusion was supported by several other animal works. For instance, the experimental result from SARS-CoV-2-infected Syrian hamsters illustrated that HCQ is unlikely to have anti-SARS-CoV-2 activity in this animal model, while favipiravir exhibits remarkable protective effect [44]. Furthermore, ferret infection model was also used to assess the antiviral candidates of SARS-CoV-2, and data indicated that HCQ/CQ have no benefit for the improvement of SARS-CoV-2-infected animals, while the adverse effects such as heart rhythm need to take more concern [45].

Table 1. $\mathrm{HCQ} / \mathrm{CQ}$ as antiviral agents in vitro

\begin{tabular}{|c|c|c|c|c|c|}
\hline Agents & $\begin{array}{l}\text { Infected } \\
\text { cells }\end{array}$ & $\begin{array}{l}\text { Dose } \\
\text { range }\end{array}$ & Mechanisms & Main findings & Ref \\
\hline $\mathrm{HCQ} / \mathrm{CQ}$ & $\begin{array}{l}\text { Vero E6 } \\
\text { cells }\end{array}$ & $\begin{array}{l}50 \mu \mathrm{M} \\
\text { for } 1 \mathrm{hr}\end{array}$ & $\begin{array}{l}\text { Elevation of the } \mathrm{pH} \\
\text { of } \\
\text { lysosome/endosome } \\
\text { that inhibits } \\
\text { SARS-CoV entry and } \\
\text { post-entry stage }\end{array}$ & $\begin{array}{l}\text { HCQ and CQ exerted } \\
\text { the anti-SARS-CoV-2 } \\
\text { effect; HCQ was safer } \\
\text { than CQ in the } \\
\text { treatment of } \\
\text { SARS-CoV-2 infection }\end{array}$ & [41] \\
\hline $\mathrm{HCQ} / \mathrm{CQ}$ & $\begin{array}{l}\text { Vero E6 } \\
\text { cells }\end{array}$ & $\begin{array}{l}0.032-100 \\
\mu \mathrm{M} \text { for } \\
24 \text { or } 48 \\
\text { hrs. }\end{array}$ & N. A & $\begin{array}{l}\text { HCQ/CQ had } \\
\text { inhibitory effect on } \\
\text { SARS-CoV-2; the } \\
\text { anti-SARS-CoV-2 } \\
\text { activity of HCQ was } \\
\text { more potent than CQ. }\end{array}$ & [6] \\
\hline CQ & $\begin{array}{l}\text { Vero E6 } \\
\text { cells }\end{array}$ & $\begin{array}{l}10 \mu \mathrm{M} \\
\text { for } 48 \\
\text { hrs }\end{array}$ & $\begin{array}{l}\text { Inhibition of the } \\
\text { entry, and post-entry } \\
\text { stage of the } \\
\text { SARS-CoV-2 } \\
\text { infection }\end{array}$ & $\begin{array}{l}\text { CQ was effective to } \\
\text { protect against the } \\
\text { spread of SARS-CoV-2 }\end{array}$ & [39] \\
\hline CQ & $\begin{array}{l}\text { Vero E6 } \\
\text { cells and } \\
\text { HEK293T } \\
\text { cells }\end{array}$ & $\begin{array}{l}1-10-100 \\
\mu \mathrm{M} \text { for } 1 \\
\mathrm{hr}\end{array}$ & $\begin{array}{l}\text { Inhibition of the } \\
\text { TMPRSS2 and } \\
\text { CTSL-dependent } \\
\text { entry of SARS-CoV-2 }\end{array}$ & $\begin{array}{l}\text { CQ had no effect in the } \\
\text { control of SARS-CoV-2 } \\
\text { infection in vitro }\end{array}$ & [42] \\
\hline
\end{tabular}

$\mathrm{CQ}$, chloroquine; HCQ, hydroxychloroquine; CTSL, cathepsin L; N.A, not applicable

Up to date, due to the biological safety issue and strict regulation applied for the personnel and facilities handling SARS-CoV-2, both the in vitro work and animal study on SARS-CoV-2 are still rather limited. There is an urgent need to establish more animal models with SARS-CoV-2 infection for testing the potential therapeutics including HCQ and CQ in the combat against the still expanding pandemic.

\section{Clinical trials with $\mathrm{HCQ} / \mathrm{CQ}$ in COVID-19 patients}

Since HCQ/CQ have been used on malaria therapy for several decades, the rationale and safety of these two agents in clinical administration are well established. Based on the well-known role of the endocytic pathway and autophagy in the infection process of SARS-CoV-2 as discussed above, the potential therapeutic efficacy of HCQ/CQ in COVID-19 has undergone extensive clinical testing all over the world, some of the main findings are summarized in Table 2. The efficacy of HCQ or CQ has been tested in about 10 hospitals in China and the results obtained from more than 100 COVID-19 patients confirmed the benefits of HCQ/CQ treatment compared with the control group by inhibiting the exacerbation of pneumonia, promoting a virus negative conversion, and shortening the disease course, without obvious side effects [46]. Therefore, some countries such as China has included CQ in the recommendations regarding the prevention and treatment of COVID-19. However, the results from other clinical trials are not convincing and their therapeutic effects are unsatisfactory, as discussed in details below.

\section{HCQ/CQ in treatment of COVID-19}

Currently, HCQ and CQ are among most widely studied antiviral drugs evaluated for SARS-CoV-2 treatment in more than one hundred clinical trials worldwide (https://www.clinicaltrials.gov/ct2/ results? recrs $=$ \&cond $=$ Covid19\&term $=$ chloroquine\&c ntry $=\&$ state $=\&$ city $=\&$ dist $=)$. Once completed, the truth regarding the real therapeutic effects of HCQ/CQ might emerge from the mystery.

One clinical trial was conducted in Guangdong China to evaluate the therapeutic potential of CQ on COVID-19 patients. The results suggested that CQ could be an effective and available option among current proposed therapies in the patients with mild/general SARS-CoV-2 infection [10]. In this study, CQ-treated patients appeared to regain their pulmonary function quicker and get sooner recovery than those patients treated with other antiviral agents (lopinavir/ritonavir, a protease inhibitor combination treatment for human immunodeficiency virus (HIV) infection [47]). Results from another clinical study claimed that both CQ and HCQ could promote viral RNA negativity and reduce the time to clinical recovery (TTCR) in moderate form of COVID-19 [48]; one randomized controlled trial using HCQ for treatment of COVID-19 was conducted in Wuhan China and the results shown that HCQ treatment meliorated the fever and reduced the cough duration [49], suggesting that HCQ may be a potential treatment for critically COVID-19 patients. More importantly, one clinical study with critical ill COVID-19 patients demonstrated that HCQ even could significantly reduce death risk without apparent side-effect on COVID-19 patients [12].

Despite the positive results from the clinical studies as discussed above, more clinical evidence has challenged the therapeutic efficacy of HCQ/CQ on COVID-19 patients and some of clinical trials are summarized in Table 2. First, there were no significant differences in clinical symptoms, inflammatory biomarkers, length of hospital stay and 
overall mortality between control group and HCQ/CQ group [50-52] while the administration of HCQ even increased the risk of mortality [53]. Second, high-dose CQ was associated with the incidence of gastrointestinal disorder, cardiovascular lethality and QTc interval [11, 14, 54, 55], which will be discussed in details below.

There are several explanations for the ineffectiveness of $\mathrm{HCQ} / \mathrm{CQ}$ in the treatment of COVID-19 patients. A recent study by Hadjadj et al. found that patients with severe COVID-19 had impaired IFN-I activity, increased T cell apoptosis and inflammatory response, while the regulatory effect on immune response by HCQ/CQ is not potent enough to inhibit the over-activation of innate immune system [56]; another analysis suggested that the ORF3a of SARS-CoV-2 could block the fusion between autophagosomes and lysosomes, so SARS-CoV-2 can survive by escaping lysosome destruction [57], which made the role of autophagy-lysosome more complicated in the living cycle of SARS-CoV-2.

Table 2. Clinical trials and retrospective studies using HCQ/CQ in treatment of COVID-19

\begin{tabular}{|c|c|c|c|c|c|}
\hline Agents & Type of Study & Design of Treatment & Main Findings & Side Effects & Ref \\
\hline $\mathrm{HCQ} / \mathrm{CQ}$ & $\begin{array}{l}\text { Phase I } \\
\text { clinical trial } \\
\text { (open-label, randomized } \\
\text { controlled trial) }\end{array}$ & $\begin{array}{l}\mathrm{n}=48 ; 18 \text { in } \mathrm{CQ} \text { group, } 18 \text { in } \mathrm{HCQ} \text { group } \\
\text { and the rest in control group }\end{array}$ & $\begin{array}{l}\text { Both HCQ and CQ decreased the time to viral } \\
\text { RNA negativity, TTCR and duration of } \\
\text { hospitalization }\end{array}$ & Diarrhea & [48] \\
\hline HCQ & Retrospective study & $\begin{array}{l}\mathrm{n}=550 ; 502 \text { received basic treatments; } 48 \\
\text { received HCQ 200mg/day, } 7-10 \text { days } \\
\text { twice daily }\end{array}$ & $\begin{array}{l}\text { HCQ significantly reduces death risk of } \\
\text { critically COVID- } 19 \text { patients without } \\
\text { apparent toxicity }\end{array}$ & N. A & [12] \\
\hline HCQ & $\begin{array}{l}\text { Phase I } \\
\text { clinical trial } \\
\text { (randomized-clinical trial) }\end{array}$ & $\begin{array}{l}\mathrm{n}=62 ; 31 \text { in the standard treatment } \\
\text { group; } 31 \text { in the HCQ-treated group } \\
(400 \mathrm{mg} / \text { day, } 5 \text { days) }\end{array}$ & $\begin{array}{l}\text { Shorten the TTCR and promoted the } \\
\text { absorption of pneumonia. }\end{array}$ & $\begin{array}{l}\text { Diarrhea, nausea, } \\
\text { fatigue, chest tightness }\end{array}$ & [49] \\
\hline HCQ & $\begin{array}{l}\text { Phase II } \\
\text { clinical trial }\end{array}$ & $\begin{array}{l}\mathrm{n}=211 \text {; received HCQ after } \\
\text { post-exposure prophylaxis (PEP) }\end{array}$ & $\begin{array}{l}\text { After PEP using HCQ, PCR tests of all } \\
\text { individuals were negative }\end{array}$ & $\begin{array}{l}\text { Diarrhea or loose stool, } \\
\text { skin rash and } \\
\text { bradycardia }\end{array}$ & [54] \\
\hline HCQ & $\begin{array}{l}\text { Phase I } \\
\text { clinical trial (multicenter, } \\
\text { randomized, open-label, } \\
\text { controlled trial) }\end{array}$ & $\begin{array}{l}\mathrm{n}=33 ; 21 \text { in HCQ group, } 12 \text { in the } \\
\text { standard of care treatment group }\end{array}$ & $\begin{array}{l}\text { No significant clinical benefit of HCQ was } \\
\text { observed }\end{array}$ & $\begin{array}{l}\text { Headache, } \\
\text { dizziness. } \\
\text { gastritis, diarrhea, } \\
\text { nausea and } \\
\text { photophobia }\end{array}$ & [14] \\
\hline HCQ & Retrospective analysis & $\begin{array}{l}\mathrm{n}=37 ; 28 \text { in HCQ group, } 9 \text { in the } \\
\text { standard of care treatment group }\end{array}$ & $\begin{array}{l}\text { No significant clinical benefit of HCQ was } \\
\text { observed }\end{array}$ & N. A & [14] \\
\hline HCQ & $\begin{array}{l}\text { Phase II } \\
\text { clinical trial } \\
\text { (multicenter, } \\
\text { randomized-controlled trial) }\end{array}$ & $\begin{array}{l}\mathrm{n}=194 ; 97 \text { in HCQ group, } 97 \text { in control } \\
\text { group }\end{array}$ & $\begin{array}{l}\text { No significant differences in clinical } \\
\text { outcomes and overall mortality }\end{array}$ & N. A & [50] \\
\hline HCQ & $\begin{array}{l}\text { Phase II } \\
\text { clinical trial (Randomized } \\
\text { controlled open label trial) }\end{array}$ & $\begin{array}{l}\mathrm{n}=89 ; 44 \text { in HCQ group; } 45 \text { in the } \\
\text { favipiravir }+ \text { interferon } \beta-1 \text { b group }\end{array}$ & $\begin{array}{l}\text { No significant differences in clinical signs } \\
\text { and symptoms, inflammatory biomarkers, } \\
\text { length of hospital stay, and mortality rate. } \\
\text { HCQ has no proven clinical effects }\end{array}$ & N. A & [51] \\
\hline HCQ & $\begin{array}{l}\text { Phase II } \\
\text { clinical trial (open-label and } \\
\text { randomize-controlled } \\
\text { clinical trial) }\end{array}$ & $\begin{array}{l}\mathrm{n}=293 ; 157 \text { received HCQ ( } 800 \mathrm{mg} \text { once, } \\
\text { followed by } 400 \mathrm{mg}, 6 \text { days once daily), } \\
\text { the rest received standard care }\end{array}$ & $\begin{array}{l}\text { No significant differences in the risk of } \\
\text { hospitalization and time to recover from } \\
\text { symptoms }\end{array}$ & N. A & [52] \\
\hline HCQ & Retrospective analysis & $\begin{array}{l}\mathrm{n}=1,669 ; 696 \text { in HCQ group, } 973 \text { in } \\
\text { treatment without HCQ group }\end{array}$ & $\begin{array}{l}\text { HCQ had no benefit on mortality in } \\
\text { COVID-19 patients.; but increased the risk of } \\
\text { mortality }\end{array}$ & N. A & [53] \\
\hline HCQ & Retrospective analysis & $\begin{array}{l}n=60 ; 30 \text { in febuxostat group, } 30 \text { in HCQ } \\
\text { group }\end{array}$ & No significant efficacy in clinical symptoms & $\begin{array}{l}\text { Retinal toxicity, cardiac } \\
\text { toxicity, QTc interval } \\
\text { prolongation }\end{array}$ & [55] \\
\hline HCQ & $\begin{array}{l}\text { Phase II } \\
\text { clinical trial } \\
\text { (randomized, double-blind, } \\
\text { placebo-controlled trial) }\end{array}$ & $\begin{array}{l}\mathrm{n}=821 \text {; assigned equally into } 2 \text { groups: } \\
\text { HCQ ( } 800 \mathrm{mg} \text { in } 6 \text { to } 8 \text { hours, then } 600 \\
\text { mg daily for } 4 \text { additional days) and } \\
\text { placebo }\end{array}$ & $\begin{array}{l}\text { The incidence of COVID-19 had no } \\
\text { significant difference }\end{array}$ & $\begin{array}{l}\text { Nausea, loose stools, } \\
\text { abdominal discomfort }\end{array}$ & [58] \\
\hline CQ & $\begin{array}{l}\text { Phase I } \\
\text { randomized clinical trial }\end{array}$ & $\begin{array}{l}\mathrm{n}=22 ; 10 \text { in CQ } 500 \mathrm{mg} / \text { day, twice-daily } \\
\text { for } 10 \text { days; } 12 \text { in Lopinavir/Ritonavir } \\
400 / 100 \mathrm{mg} \text {, twice-daily for } 10 \text { days }\end{array}$ & $\begin{array}{l}\text { Patients treated with CQ regained their } \\
\text { pulmonary function quicker and recovered } \\
\text { sooner }\end{array}$ & $\begin{array}{l}\text { No serious adverse } \\
\text { events }\end{array}$ & [10] \\
\hline CQ & $\begin{array}{l}\text { Phase II } \\
\text { clinical trial }\end{array}$ & $\begin{array}{l}\mathrm{n}=81 ; 41 \text { in CQ high-dosage group ( } 600 \\
\mathrm{mg} / \text { day, } 10 \text { day twice daily), } 40 \text { in the } \\
\text { CQ low-dosage group ( } 450 \mathrm{mg} / \text { day, } 10 \\
\text { day, twice daily) }\end{array}$ & $\begin{array}{l}\text { No clinical benefit of CQ was observed, and } \\
\text { high-dose CQ associated with lethality and } \\
\text { QTc interval }\end{array}$ & $\begin{array}{l}\text { QTc interval } \\
\text { prolongation }\end{array}$ & [11] \\
\hline
\end{tabular}

CQ, chloroquine; HCQ, hydroxychloroquine; COVID-19, novel coronavirus infection 2019; IL-6, interleukin-6; PCR, polymerase chain reaction; ICU, Intensive Care Unit; CT, Computer Tomography; CRP, curved planar reformation; COVID-19, novel coronavirus infection 2019; rRT-PCR, reverse real-time polymerase chain reaction; N.A; not applicable; PEP, post-exposure prophylaxis; TTCR, time to clinical recovery. 


\section{Combinational therapy of HCQ with azithromycin in treatment of COVID-19}

In order to improve the clinical therapeutic effect of current antiviral agents, one important approach is to use combinational therapy. Among various combinations, a couple of clinical studies have been carried out on the combination of HCQ and azithromycin (AZ). AZ is a synthetic macrolide antibiotic effective against a wide range of bacterial and mycobacterial infections, which has been prescribed to patients infected with SARS-CoV previously [59]. Lately, AZ has been identified as a potential candidate for the treatment of SARS-CoV-2, and its effect has been evaluated by in vitro, in silico drug screens and clinical trials [60]. However, the synergistic effect of HCQ and AZ in the treatment of SARS-CoV-2 is still questionable, as summarized in Table 3.

In France, one clinical trial with 36 participants indicated that combination of HCQ with AZ demonstrated a better efficacy than single drug, based on the virus clearance rate [61]. However, majority studies indicated that the combination of HCQ and AZ could not take a favorable turn of the course of SARS-CoV-2 patients. In a retrospective multicenter cohort study on totally 1,438 SARS-CoV-2 patients from 25 different hospitals in New York, analysis data revealed that the hospital fatality rate among different treatment groups did not show significant difference [62]. Consistently, a retrospective analysis of 368 patients from USA suggested that risk of ventilation had no significant difference in HCQ+AZ group from control group [63]. Whereas two studies consistently claimed that the combination of HCQ and AZ caused unfavorable side-effects, including heart failure and cardiovascular fatality within 30-days treatment period in COVID-19 patients [64, 65].

One systematic review and meta-analysis published in January 2021 indicated that the combination of HCQ and AZ increased mortality significantly, summarized from 29 articles, including randomized controlled trials, non-randomized trials and observational studies [66]. In conclusion, majority of current clinical trials on this combined treatment have not provided any optimistic outcome for their further application on COVID-19 treatment, mainly because of their ineffectiveness on COVID-19 and significant advert effects on cardiovascular system. Therefore, strict cardiovascular monitoring should be applied if this regimen is given.

\section{Side effects of $\mathrm{HCQ} / \mathrm{CQ}$ in clinical trials for treatment of COVID-19}

Although the application of HCQ/CQ is well established in malaria or autoimmune diseases for years, higher dosage seems to be a prerequisite for the anti-viral effects of HCQ/CQ against SARS-CoV-2. According to the clinical reports, suggested doses of HCQ/CQ in COVID-19 patients are significantly higher than the recommended dose for malaria treatment [68]. Significant side effects have been reported from the clinical investigations, such as anxiety, sleeplessness, gastrointestinal disorders, and cardiomyopathy, as summarized in both Table 2 and Table 3.

Table 3. Clinical trials and retrospective studies on combinational therapy of HCQ with AZ in treatment of COVID-19

\begin{tabular}{|c|c|c|c|c|c|}
\hline $\begin{array}{l}\text { Agent } \\
\mathrm{s}\end{array}$ & Type of study & $\begin{array}{l}\text { Design of } \\
\text { Treatment }\end{array}$ & Main Findings & Side effects & Ref \\
\hline $\begin{array}{l}\mathrm{HCQ} \\
+\mathrm{AZ}\end{array}$ & $\begin{array}{l}\text { Phase I } \\
\text { clinical trial } \\
\text { (open-label } \\
\text { non-randomized } \\
\text { ) }\end{array}$ & $\begin{array}{l}\mathrm{n}=42 ; 26 \text { received } \\
\mathrm{HCQ}+\mathrm{AZ}(600 \\
\mathrm{mg} / \text { day }), 16 \\
\text { were control } \\
\text { group }\end{array}$ & $\begin{array}{l}\text { HCQ treatment } \\
\text { associated with } \\
\text { viral load } \\
\text { reduction or } \\
\text { disappearance; } \\
\text { this effect is } \\
\text { reinforced by AZ }\end{array}$ & N. A & $\begin{array}{l}{[61} \\
]\end{array}$ \\
\hline $\begin{array}{l}\text { HCQ } \\
+\mathrm{AZ}\end{array}$ & $\begin{array}{l}\text { Retrospective } \\
\text { study }\end{array}$ & $\begin{array}{l}\mathrm{n}=1,438 ; 735 \text { in } \\
\mathrm{HCQ}+\mathrm{AZ} \text { group, } \\
271 \text { in } \mathrm{HCQ} \\
\text { group. } 221 \text { in } \mathrm{AZ} \\
\text { group, } 221 \text { in } \\
\text { control group. }\end{array}$ & $\begin{array}{l}\text { Abnormal } \\
\text { electrocardiogra } \\
\text { m and in-hospital } \\
\text { mortality had no } \\
\text { significant } \\
\text { difference from } \\
\text { control group }\end{array}$ & N. A & $\begin{array}{l}\text { [62 } \\
]\end{array}$ \\
\hline $\begin{array}{l}\mathrm{HCQ} \\
+\mathrm{AZ}\end{array}$ & $\begin{array}{l}\text { Retrospective } \\
\text { study }\end{array}$ & $\begin{array}{l}\mathrm{n}=368 ; 97 \text { in } \\
\text { HCQ group, } 113 \\
\text { in HCQ+AZ } \\
\text { group, } 158 \text { in no } \\
\text { HCQ group }\end{array}$ & $\begin{array}{l}\text { No reduced risk } \\
\text { of mechanical } \\
\text { ventilation after } \\
\text { treatment }\end{array}$ & N. A & $\begin{array}{l}{[63} \\
]\end{array}$ \\
\hline $\begin{array}{l}\text { HCQ } \\
+\mathrm{AZ}\end{array}$ & $\begin{array}{l}\text { Retrospective } \\
\text { study }\end{array}$ & $\begin{array}{l}\mathrm{n}=251 ; \text { All } \\
\text { patients received } \\
\mathrm{HCQ}+\mathrm{AZ}, \mathrm{HCQ} \\
\text { was given at } 400 \\
\text { mg once } \\
\text { followed by } 200 \\
\text { mg } 4 \text { days twice } \\
\text { daily, AZ } 500 \\
\text { mg/day, once } \\
\text { daily for } 5 \text { days }\end{array}$ & $\begin{array}{l}\text { QTc interval } \\
\text { prolongation and } \\
\text { induction of } \\
\text { torsade de } \\
\text { pointes, strict } \\
\text { QTc interval } \\
\text { monitoring } \\
\text { should be } \\
\text { applied if this } \\
\text { regimen is given }\end{array}$ & $\begin{array}{l}\text { QTc interval } \\
\text { prolongation } \\
\text { and induction } \\
\text { of torsade de } \\
\text { pointes }\end{array}$ & $\begin{array}{l}{[65} \\
]\end{array}$ \\
\hline $\begin{array}{l}\text { HCQ } \\
+\mathrm{AZ}\end{array}$ & Cohort study & $\begin{array}{l}\mathrm{n}=1,941,802 ; \\
956,374 \text { in } \mathrm{HCQ} \\
\text { group and } \\
310,350 \text { in } \\
\text { sulfasalazine } \\
\text { group, 323,122 in } \\
\text { HCQ+AZ group } \\
\text { and 351,956 in } \\
\text { HCQ+amoxicilli } \\
\text { n group }\end{array}$ & $\begin{array}{l}\text { The combination } \\
\text { of AZ and HCQ } \\
\text { increased the risk } \\
\text { of heart failure } \\
\text { and } \\
\text { cardiovascular } \\
\text { mortality }\end{array}$ & $\begin{array}{l}\text { Angina/chest } \\
\text { pain; heart } \\
\text { failure; } \\
\text { cardiovascula } \\
\text { r mortality }\end{array}$ & $\begin{array}{l}{[67} \\
]\end{array}$ \\
\hline
\end{tabular}

The most common side effects of HCQ/CQ were gastrointestinal responses, such as vomiting and diarrhea, which widely affect the recovery of patients $[20,49,54,58]$. Long-term administration of these two drugs would cause plenty of adverse effects, such as retinopathy, circular defects, diametric defects in the retina and cardiomyopathy [27, 55]. COVID-19 patients could be more vulnerable to side effects, particularly among the high-risk patients group: the elderly and patients with chronic diseases, such as diabetes or cardiovascular diseases. In addition, cardiotoxicity caused by CQ seems specifically relevant to the infection of SARS-CoV-2. For instance 
the myocarditis is a very common complication after infecting SARS-CoV-2, especially in the combination with QTc interval prolonging drugs, for example amiodarone, macrolide antibiotics (such as AZ), ondansetron, and many others [41]. Likewise, the notable QTc interval prolongation $(>500 \mathrm{~ms})$ with a high risk for arrhythmia was found in the case of co-treatment with HCQ and AZ [65, 67, 69]. Both HCQ and CQ are mainly metabolized via the liver and kidney and have long half-lives (approximately 1-2 months) [70]. Therefore, long-term monitoring for their renal and hepatotoxicity is necessary.

Although HCQ and CQ share similar chemical structures and both of them have potential anti-SARS-CoV-2 activity as discussed earlier, results from some clinical trials suggest that HCQ has fewer side effects and higher tolerated doses in comparison to CQ [71]. Thus, CQ has more restrictions in treatment of COVID-19 as CQ overdose can rapidly cause sever life-threaten toxicity, corresponding to a dose of $5 \mathrm{~g}$ in adults could result in death without treatment [72]. There two major reasons have been proposed for this: (i) The maximum tolerable dose for HCQ is $1,200 \mathrm{mg}$, which has an antiviral effect equivalent to $750 \mathrm{mg} C Q$ (for which the maximum tolerable dose is $500 \mathrm{mg}$ ) [73]; (ii) CQ could exert various advert effects on fetal development, therefore, HCQ may be a safer option comparing to CQ, for the pregnant women with COVID-19 [74], and data from rheumatological research indicates that $C Q$ is linked to a higher retinopathy incidence rate when compared with HCQ [75].

In conclusion, it is important to understand the exact antiviral mechanism of HCQ/CQ, then optimize the application of $\mathrm{HCQ} / \mathrm{CQ}$ in battling against SARS-CoV-2 while consider the toxicological risks and necessary care for patients after drug administration.

\section{Summary and Perspectives}

Given the COVID-19 global pandemic, there is an urgent need for effective and available antiviral therapy and vaccines. Despite the long history of clinical application of HCQ and CQ in various human diseases, with advantages of inexpensive and easily accessible, their therapeutic value in treatment of COVID-19 remains questionable. The mystery or controversy comes from several aspects. First, both CQ and HCQ could inhibit the transport of SARS-CoV-2 along the endocytic pathway via neutralizing the $\mathrm{pH}$ value of acidic organelles (endosome and lysosome) in host cells, which have been verified by several in vitro studies. Second, insufficient and controversial results from SARSCoV-2 animal models, which greatly challenged the in vivo antiviral effect of HCQ/CQ. Third, most clinical trials failed to prove the efficacy of HCQ/CQ on COVID-19 patients but discover obvious cardiovascular toxicity and gastrointestinal responses from various clinical trials. As a result, in June 2020 FDA revoked its authorization for the emergency use of HCQ/CQ in COVID-19 patients (https://www.fda.gov/news-events/press-announce ments/coronavirus-covid-19-update-fda-revokes-em ergency-use-authorization-chloroquine-and).

At present, there are still numerous clinical trials ongoing around the world using HCQ/CQ in treatment of COVID-19, either alone or in combination with other therapeutics. To move forward, there are important challenges for the scientific community to conduct more work to repurpose these two ancient drugs in the combat against this deadly COVID-19 pandemic. Specifically, more mechanistic studies are necessary to fully discover the exact targets of HCQ/CQ on both SARS-CoV-2 and host cells, to clarify the potential role of autophagy and lysosome on the process of viral replication. Furthermore, more animal works are needed to reveal the pharmacokinetic characteristics of HCQ/CQ and understand the possible reason for the inconsistent effect of these two agents between in vitro and in vivo investigations. Last and most importantly, it will be critically important to conduct more clinical trials to optimize the clinical application, including potential combined therapy, to enhance the therapeutic efficacy and to reduce the adverse effects on patients. Hopefully, all the research work not only resolve the mystery regarding the therapeutic efficacy of these two drugs in COVID-19, also add more light at the end of tunnel in our fight against COVID-19.

\section{Acknowledgements}

This work was supported by following funding to J Zhou: the Guangxi Natural Science Foundation Key Grant [2017GXNSFDA198020], Guangxi Medical University Training Program for Distinguished Young Scholars [2016], Guangxi First-Class Discipline Project for Basic Medicine Sciences (GXFCDPBMS-2018); and the following funding to HM Shen: Singapore National Medical Research Council (NMRC/CIRG/1490/2018), Singapore Ministry of Education (MOE) (MOE2018-T2-1-060) and University of Macau (UM) SRG2020-00002-FHS and CPG2020-00029-FHS.

\section{Abbreviations}

AZ: azithromycin; ACE2: angiotensin converting enzyme 2; CoV: coronavirus; COVID-19: coronavirus disease 2019; CQ: chloroquine; CRP: curved planar 
reformation; CT: computer tomography; CTSL: cathepsin L; DMVs: double-membrane vesicles; HCQ: hydroxychloroquine; HIV: human immunodeficiency virus; ICU: intensive care unit; IL-6: interleukin-6; MERS-CoV: Middle East respiratory syndrome coronavirus; MHV: mouse hepatitis virus; PCR: polymerase chain reaction; rRT-PCR: reverse real-time polymerase chain reaction; PEP: post-exposure prophylaxis; SARS-CoV: severe acute respiratory syndrome coronavirus; SARS-CoV-2: severe acute respiratory syndrome coronavirus 2; TTCR: time to clinical recovery.

\section{Competing Interests}

The authors have declared that no competing interest exists.

\section{References}

1. Yang N, Shen HM. Targeting the Endocytic Pathway and Autophagy Process as a Novel Therapeutic Strategy in COVID-19. Int J Biol Sci. 2020; 16: 1724-31.

2. Sun I, Chen Y, Fan X, Wang X, Han Q, Liu Z. Advances in the use of chloroquine and hydroxychloroquine for the treatment of COVID-19. Postgraduate Medicine. 2020; 132: 604-13.

3. Cirino G, Ahluwalia A. The many mechanisms of action of Chloroquine: to use or not to use (in COVID-19) that is the question. Br J Pharmacol. 2020; 177: $3361-2$.

4. Serafin MB, Bottega A, Foletto VS, da Rosa TF, Horner A, Horner R. Drug repositioning is an alternative for the treatment of coronavirus COVID-19. Int J Antimicrob Agents. 2020; 55: 105969.

5. de Wilde AH, Jochmans D, Posthuma CC, Zevenhoven-Dobbe JC, van Nieuwkoop S, Bestebroer TM, et al. Screening of an FDA-approved compound library identifies four small-molecule inhibitors of Middle East respiratory syndrome coronavirus replication in cell culture. Antimicrob Agents Chemother. 2014; 58: 4875-84

6. Yao X, Ye F, Zhang M, Cui C, Huang B, Niu P, et al. In Vitro Antiviral Activity and Projection of Optimized Dosing Design of Hydroxychloroquine for the Treatment of Severe Acute Respiratory Syndrome Coronavirus 2 (SARS-CoV-2). Clin Infect Dis. 2020; 71: 732-9.

7. Ali MJ, Hanif M, Haider MA, Ahmed MU, Sundas F, Hirani A, et al. Treatment Options for COVID-19: A Review. Front Med (Lausanne). 2020; 7: 480.

8. Şimşek Yavuz S, Ünal S. Antiviral treatment of COVID-19. Turk J Med Sci. 2020; 50: 611-9.

9. Roques P, Thiberville SD, Dupuis-Maguiraga L, Lum FM, Labadie K, Martinon F, et al. Paradoxical Effect of Chloroquine Treatment in Enhancing Chikungunya Virus Infection. Viruses. 2018; 10.

10. Huang M, Tang T, Pang P, Li M, Ma R, Lu J, et al. Treating COVID-19 with Chloroquine. J Mol Cell Biol. 2020; 12: 322-5.

11. Borba MGS, Val FFA, Sampaio VS, Alexandre MAA, Melo GC, Brito M, et al. Effect of High vs Low Doses of Chloroquine Diphosphate as Adjunctive Therapy for Patients Hospitalized With Severe Acute Respiratory Syndrome Coronavirus 2 (SARS-CoV-2) Infection: A Randomized Clinical Trial. JAMA Netw Open. 2020; 3: e208857.

12. $\mathrm{Yu}$ B, Li C, Chen $\mathrm{P}$, Zhou N, Wang L, Li J, et al. Low dose of hydroxychloroquine reduces fatality of critically ill patients with COVID-19. Sci China Life Sci. 2020; 63: 1515-21.

13. Bansal P, Goyal A, Cusick At, Lahan S, Dhaliwal HS, Bhyan P, et al. Hydroxychloroquine: a comprehensive review and its controversial role in coronavirus disease 2019. Ann Med. 2021; 53: 117-34.

14. Chen CP, Lin YC, Chen TC, Tseng TY, Wong HL, Kuo CY, et al. A multicenter, randomized, open-label, controlled trial to evaluate the efficacy and tolerability of hydroxychloroquine and a retrospective study in adult patients with mild to moderate coronavirus disease 2019 (COVID-19). PLoS One. 2020; 15: e0242763.

15. Geleris J, Sun Y, Platt J, Zucker J, Baldwin M, Hripcsak G, et al. Observational Study of Hydroxychloroquine in Hospitalized Patients with Covid-19. N Engl Med. 2020; 382: 2411-8.

16. Elavarasi A, Prasad M, Seth T, Sahoo RK, Madan K, Nischal N, et al. Chloroquine and Hydroxychloroquine for the Treatment of COVID-19: a Systematic Review and Meta-analysis. Journal of general internal medicine. 2020; 35: 3308-14.

17. Gasmi A, Peana M, Noor S, Lysiuk R, Menzel A, Gasmi Benahmed A, et al. Chloroquine and hydroxychloroquine in the treatment of COVID-19: the never-ending story. Applied microbiology and biotechnology. 2021; 105: $1333-43$
18. Hashem AM, Alghamdi BS, Algaissi AA, Alshehri FS, Bukhari A, Alfaleh MA, et al. Therapeutic use of chloroquine and hydroxychloroquine in COVID-19 and other viral infections: A narrative review. Travel medicine and infectious disease. 2020; 35: 101735 .

19. Shah RR. Chloroquine and hydroxychloroquine for COVID-19: Perspectives on their failure in repurposing. Journal of clinical pharmacy and therapeutics. 2021; 46: 17-27.

20. Srinivasa A, Tosounidou S, Gordon C. Increased Incidence of Gastrointestinal Side Effects in Patients Taking Hydroxychloroquine: A Brand-related Issue? J Rheumatol. 2017; 44: 398

21. Achan J, Talisuna AO, Erhart A, Yeka A, Tibenderana JK, Baliraine FN, et al. Quinine, an old anti-malarial drug in a modern world: role in the treatment of malaria. Malar J. 2011; 10: 144.

22. Coatney GR. Pitfalls in a discovery: the chronicle of chloroquine. Am J Trop Med Hyg. 1963; 12: 121-8.

23. Slater AF. Chloroquine: mechanism of drug action and resistance in Plasmodium falciparum. Pharmacol Ther. 1993; 57: 203-35.

24. Ben-Zvi I, Kivity S, Langevitz P, Shoenfeld Y. Hydroxychloroquine: from malaria to autoimmunity. Clin Rev Allergy Immunol. 2012; 42: 145-53.

25. Verbaanderd C, Maes H, Schaaf MB, Sukhatme VP, Pantziarka P, Sukhatme V, et al. Repurposing Drugs in Oncology (ReDO)-chloroquine and hydroxychloroquine as anti-cancer agents. Ecancermedicalscience. 2017; 11: 781.

26. Savarino A, Di Trani L, Donatelli I, Cauda R, Cassone A. New insights into the antiviral effects of chloroquine. Lancet Infect Dis. 2006; 6: 67-9.

27. Schrezenmeier E, Dorner T. Mechanisms of action of hydroxychloroquine and chloroquine: implications for rheumatology. Nat Rev Rheumatol. 2020; 16: $155-66$

28. Kim D, Lee JY, Yang JS, Kim JW, Kim VN, Chang H. The Architecture of SARS-CoV-2 Transcriptome. Cell. 2020; 181: 914-21.e10.

29. Oinfen $Z$, Jinming $C$, Xiaojun $H$, Huanying $Z$, Jicheng $H$, Ling $F$, et al. The life cycle of SARS coronavirus in Vero E6 cells. J Med Virol. 2004; 73: 332-7.

30. Pelkmans L, Helenius A. Insider information: what viruses tell us about endocytosis. Curr Opin Cell Biol. 2003; 15: 414-22.

31. Nour AM, Modis Y. Endosomal vesicles as vehicles for viral genomes. Trends Cell Biol. 2014; 24: 449-54

32. Soderstrom K. Viral Replication. In: Bylund SJEaDB, editor. xPharm: The Comprehensive Pharmacology Reference. Elisevier: East Carolina University, Greenville, USA, Copyright @ 2007 Elsevier Inc. ; 2008.

33. Zumla A, Chan JF, Azhar EI, Hui DS, Yuen KY. Coronaviruses - drug discovery and therapeutic options. Nat Rev Drug Discov. 2016; 15: 327-47.

34. Shen HM, Mizushima N. At the end of the autophagic road: an emerging understanding of lysosomal functions in autophagy. Trends Biochem Sci. 2014; 39: 61-71.

35. Brest P, Benzaquen J, Klionsky DJ, Hofman P, Mograbi B. Open questions for harnessing autophagy-modulating drugs in the SARS-CoV-2 war: hope or hype? Autophagy. 2020; 16: 2267-70.

36. Abdoli A, Alirezaei M, Mehrbod P, Forouzanfar F. Autophagy: The multi-purpose bridge in viral infections and host cells. Rev Med Virol. 2018; 28: e1973.

37. Zhao Z, Thackray LB, Miller BC, Lynn TM, Becker MM, Ward E, et al. Coronavirus replication does not require the autophagy gene ATG5. Autophagy. 2007; 3: 581-5.

38. Shojaei S, Suresh M, Klionsky DJ, Labouta HI, Ghavami S. Autophagy and SARS-CoV-2 infection: Apossible smart targeting of the autophagy pathway. Virulence. 2020; 11: 805-10.

39. Wang M, Cao R, Zhang L, Yang X, Liu J, Xu M, et al. Remdesivir and chloroquine effectively inhibit the recently emerged novel coronavirus (2019-nCoV) in vitro. Cell Res. 2020; 30: 269-71.

40. Gevers S, Kwa MSG, Wijnans E, van Nieuwkoop C. Safety considerations for chloroquine and hydroxychloroquine in the treatment of COVID-19. Clin Microbiol Infect. 2020; 26: 1276-7.

41. Liu J, Cao R, Xu M, Wang X, Zhang $\mathrm{H}, \mathrm{Hu} \mathrm{H}$, et al. Hydroxychloroquine, a less toxic derivative of chloroquine, is effective in inhibiting SARS-CoV-2 infection in vitro. Cell Discov. 2020; 6:16.

42. Hoffmann $\mathrm{M}$, Mosbauer $\mathrm{K}$, Hofmann-Winkler $\mathrm{H}$, Kaul A, Kleine-Weber $\mathrm{H}_{\text {, }}$ Kruger N, et al. Chloroquine does not inhibit infection of human lung cells with SARS-CoV-2. Nature. 2020; 585: 588-90.

43. Maisonnasse P, Guedj J, Contreras V, Behillil S, Solas C, Marlin R, et al. Hydroxychloroquine use against SARS-CoV-2 infection in non-human primates. Nature. 2020; 585: 584-7.

44. Kaptein SJF, Jacobs S, Langendries L, Seldeslachts L, Ter Horst S, Liesenborghs $\mathrm{L}$, et al. Favipiravir at high doses has potent antiviral activity in SARS-CoV-2-infected hamsters, whereas hydroxychloroquine lacks activity. Proc Natl Acad Sci U S A. 2020; 117: 26955-65.

45. Park SJ, Yu KM, Kim YI, Kim SM, Kim EH, Kim SG, et al. Antiviral Efficacies of FDA-Approved Drugs against SARS-CoV-2 Infection in Ferrets. mBio. 2020; 11.

46. Gao J, Tian Z, Yang X. Breakthrough: Chloroquine phosphate has shown apparent efficacy in treatment of COVID-19 associated pneumonia in clinical studies. Biosci Trends. 2020; 14: 72-3.

47. Lv Z, Chu Y, Wang Y. HIV protease inhibitors: a review of molecular selectivity and toxicity. HIV AIDS (Auckl). 2015; 7: 95-104.

48. Chen L, Zhang Z-Y, Fu J-G, Feng Z-P, Zhang S-Z, Han Q-Y, et al. Efficacy and safety of chloroquine or hydroxychloroquine in moderate type of COVID-19: a 
prospective open-label randomized controlled study. 2020: 2020.06.19.20136093.

49. Chen Z, Hu J, Zhang Z, Jiang S, Han S, Yan D, et al. Efficacy of hydroxychloroquine in patients with COVID-19: results of a randomized clinical trial. 2020: 2020.03.22.20040758.

50. Abd-Elsalam S, Esmail ES, Khalaf M, Abdo EF, Medhat MA, Abd El Ghafar MS, et al. Hydroxychloroquine in the Treatment of COVID-19: A Multicenter Randomized Controlled Study. Am J Trop Med Hyg. 2020; 103: 1635-9.

51. Khamis F, Al Naabi H, Al Lawati A, Ambusaidi Z, Al Sharji M, Al Barwani U, et al. Randomized controlled open label trial on the use of favipiravir combined with inhaled interferon beta- $1 \mathrm{~b}$ in hospitalized patients with moderate to severe COVID-19 pneumonia. Int J Infect Dis. 2021; 102: 538-43.

52. Mitjà $\mathrm{O}$, Corbacho-Monné $\mathrm{M}$, Ubals $\mathrm{M}$, Tebe $\mathrm{C}$, Peñafiel J, Tobias $\mathrm{A}$, et al. Hydroxychloroquine for Early Treatment of Adults with Mild Covid-19: A Randomized-Controlled Trial. Clin Infect Dis. 2020.

53. Sands K, Wenzel R, McLean L, Korwek K, Roach J, Miller K, et al. No clinical benefit in mortality associated with hydroxychloroquine treatment in patients with COVID-19. Int J Infect Dis. 2021; 104: 34-40.

54. Lee SH, Son H, Peck KR. Can post-exposure prophylaxis for COVID-19 be considered as an outbreak response strategy in long-term care hospitals? Int J Antimicrob Agents. 2020; 55: 105988.

55. Davoodi L, Abedi SM, Salehifar E, Alizadeh-Navaei R, Rouhanizadeh H, Khorasani G, et al. Febuxostat therapy in outpatients with suspected COVID-19: A clinical trial. Int J Clin Pract. 2020; 74: e13600.

56. Hadjadj J, Yatim N, Barnabei L, Corneau A, Boussier J, Smith N, et al. Impaired type I interferon activity and inflammatory responses in severe COVID-19 patients. Science. 2020; 369: 718-24.

57. Miao G, Zhao H, Li Y, Ji M, Chen Y, Shi Y, et al. ORF3a of the COVID-19 virus SARS-CoV-2 blocks HOPS complex-mediated assembly of the SNARE complex required for autolysosome formation. Dev Cell. 2020.

58. Boulware DR, Pullen MF, Bangdiwala AS, Pastick KA, Lofgren SM, Okafor EC, et al. A Randomized Trial of Hydroxychloroquine as Postexposure Prophylaxis for Covid-19. N Engl J Med. 2020; 383: 517-25.

59. Kawamura K, Ichikado K, Takaki M, Eguchi Y, Anan K, Suga M. Adjunctive therapy with azithromycin for moderate and severe acute respiratory distress syndrome: a retrospective, propensity score-matching analysis of prospectively collected data at a single center. Int J Antimicrob Agents. 2018; 51: 918-24.

60. Oliver ME, Hinks TSC. Azithromycin in viral infections. Rev Med Virol. 2020: e2163.

61. Gautret P, Lagier JC, Parola P, Hoang VT, Meddeb L, Mailhe M, et al. Hydroxychloroquine and azithromycin as a treatment of COVID-19: results of an open-label non-randomized clinical trial. Int J Antimicrob Agents. 2020; 56 : 105949.

62. Rosenberg ES, Dufort EM, Udo T, Wilberschied LA, Kumar J, Tesoriero J, et al. Association of Treatment With Hydroxychloroquine or Azithromycin With In-Hospital Mortality in Patients With COVID-19 in New York State. JAMA. 2020; 323: 2493-502.

63. Magagnoli J, Narendran S, Pereira F, Cummings T, Hardin JW, Sutton SS, et al. Outcomes of hydroxychloroquine usage in United States veterans hospitalized with Covid-19. medRxiv. 2020.

64. Lane JCE, Weaver J, Kostka K, Duarte-Salles T, Abrahao MTF, Alghoul H, et al. Risk of hydroxychloroquine alone and in combination with azithromycin in the treatment of rheumatoid arthritis: a multinational, retrospective study. Lancet Rheumatol. 2020; 2: e698-e711.

65. Chorin E, Wadhwani L, Magnani S, Dai M, Shulman E, Nadeau-Routhier C, et al. QT interval prolongation and torsade de pointes in patients with COVID-19 treated with hydroxychloroquine/azithromycin. Heart Rhythm. 2020; 17: 1425-33.

66. Fiolet T, Guihur A, Rebeaud ME, Mulot M, Peiffer-Smadja N, Mahamat-Saleh Y. Effect of hydroxychloroquine with or without azithromycin on the mortality of coronavirus disease 2019 (COVID-19) patients: a systematic review and meta-analysis. Clin Microbiol Infect. 2021; 27: 19-27.

67. C.E.Lane J, Weaver J, Kostka K, Duarte-Salles T, Abrahao MTF, Alghoul H, et al. Safety of hydroxychloroquine, alone and in combination with azithromycin, in light of rapid wide-spread use for COVID-19: a multinational, network cohort and self-controlled case series study. 2020: 2020.04.08.20054551

68. Prayuenyong P, Kasbekar AV, Baguley DM. Clinical Implications of Chloroquine and Hydroxychloroquine Ototoxicity for COVID-19 Treatment: A Mini-Review. Front Public Health. 2020; 8: 252.

69. Mercuro NJ, Yen CF, Shim DJ, Maher TR, McCoy CM, Zimetbaum PJ, et al. Risk of QT Interval Prolongation Associated With Use of Hydroxychloroquine With or Without Concomitant Azithromycin Among Hospitalized Patients Testing Positive for Coronavirus Disease 2019 (COVID-19). JAMA Cardiol. 2020; 5: 1036-41.

70. Plantone D, Koudriavtseva T. Current and Future Use of Chloroquine and Hydroxychloroquine in Infectious, Immune, Neoplastic, and Neurological Diseases: A Mini-Review. Clin Drug Investig. 2018; 38: 653-71.

71. Vaidya NA, Vyas R. Computational Studies of Hydroxychloroquine and Chloroquine Metabolites as Possible Candidates for Coronavirus (COVID-19) Treatment. Front Pharmacol. 2020; 11: 569665.

72. Della Porta A, Bornstein K, Coye A, Montrief T, Long B, Parris MA. Acute chloroquine and hydroxychloroquine toxicity: A review for emergency clinicians. Am J Emerg Med. 2020; 38: 2209-17.
73. Furst DE, Lindsley H, Baethge B, Botstein GR, Caldwell J, Dietz F, et al. Dose-loading with hydroxychloroquine improves the rate of response in early, active rheumatoid arthritis: a randomized, double-blind six-week trial with eighteen-week extension. Arthritis Rheum. 1999; 42: 357-65.

74. Liu H, Wang LL, Zhao SJ, Kwak-Kim J, Mor G, Liao AH. Why are pregnant women susceptible to COVID-19? An immunological viewpoint. J Reprod Immunol. 2020; 139: 103122.

75. Marmor MF, Kellner U, Lai TY, Melles RB, Mieler WF. Recommendations on Screening for Chloroquine and Hydroxychloroquine Retinopathy (2016 Revision). Ophthalmology. 2016; 123: 1386-94. 